\title{
Development Strategy of China's UHV AC Engineering Based on the SWOT - PEST Analysis
}

\author{
Wei Meng \\ North China Electric Power University (Baoding) \\ Baoding, Hebei, China \\ Mengwei8813@126.com
}

\author{
Feng Kong \\ North China Electric Power University (Baoding) \\ Baoding, Hebei, China
}

\author{
Liang Sun \\ State Grid Hunan electric power transmission \& transformation Engineering Company \\ Changsha, China
}

\begin{abstract}
To analyze the internal environment and external environment of UHV AC engineering, We analyzed the main advantages and challenges of UHV with the SWOT-PEST method. We have come to the conclusion that we should vigorously develop the UHP. What is more, According to the characteristics of UHV project development, the future direction and concrete development measures of UHV AC engineering are systematically discussed and we creatively put forward the development strategy of overseas UHV project.
\end{abstract}

Keywords-UHV AC Engineering; SWOT-PEST; Overseas Engineering; Development Strategy

\section{INTRODUCTION}

All of us know that more than $80 \%$ of China's coal, water, wind and solar energy are distributed in the northwest, but more than $70 \%$ of the electricity is concentrated in the central and eastern regions. How can the energy of the western region be transported to the eastern economy developed areas has long been problems.

the UHV transmission technology which leading by the State Grid Corporation is recognized by the community, the most complex and most difficult of a power technology so far,[1] is also the world's most advanced transmission technology. UHV transmission has the advantages of less project space, long distance transportation, large transmission capacity and low transmission loss, and can arrange energy more safely, more efficiently and more environmentally friendly. In addition, with the recent "power development" thirteen five "plan" release, UHV transmission will become China's future power development focus areas.

At present, the State Grid Corporation has put on six AC transmission projects, namely, Jindongnan - Nanyang- Jingmen, Huainan - Zhejiang - Shanghai, Zhejiang - Fuzhou, Huainan -
Nanjing - Shanghai (excluding the Soviet Union through the river project), Ximeng - Shandong, Mengxi - Tianjin South Project. These projects are safe and stable operation, they absolutely play a key function of power transmission artery.

\section{ANALYSIS OF INTERNAL AND EXTERNAL ENVIRONMENT OF UHV ENGINEERING BASED ON SWOT - PEST.}

SWOT analysis also known as that the situation analysis, proposed in the early 80s of the 20th century by the United States San Francisco University management professor Velick. It often used in corporate strategy development, competitor analysis and other occasions The analysis Includes the strengths, weaknesses, opportunities, and threats of the business. SWOT analysis method is the guiding ideology in the overall grasp of the main advantages of competitive entities, disadvantages and external environment under the premise of the threat, to develop a competitive decision-making strategy, to overcome the disadvantages and seize the opportunity to eliminate the threat.[2]

PEST analysis is a way to help companies review their external macro environment. It analyzes the main external environmental factors that influence the four major categories of politics, economic, social and technological. Through the analysis of these four factors makes the enterprise to fully grasp the macro environment and then assess its strategic objectives and development strategies to develop the impact.

On the basis of the current environment of UHV AC engineering, we build SWOT-PEST model which holds the factors influencing the development of special high-voltage exchange engineering together such as politics (P), economy $(\mathrm{E})$, society (S), and technology (T) Joint analysis. The various factors are summarized as follows.[3] 
TABLE I.

ANALYSIS TABLE BASED ON THE SWOT-PEST

\begin{tabular}{|c|c|c|c|c|c|}
\hline \multicolumn{2}{|c|}{ SWOT-PEST } & $\mathbf{P}$ & $\mathbf{E}$ & $\mathbf{S}$ & $\mathbf{T}$ \\
\hline \multirow[t]{2}{*}{ SW } & Superiority & $\begin{array}{l}\text { The Belt and Road } \\
\text { Initiatives "provides } \\
\text { policy support for the" } \\
\text { going out "of the UHV } \\
\text { project }\end{array}$ & $\begin{array}{l}\text { The power price is lower by 6- } \\
\text { 15penny/Kwh Northwest energy } \\
\text { base to the eastern and central load } \\
\text { center area through the UHV power } \\
\text { grid to send t, to the net floor price } \\
\text { is lower than the eastern central by } \\
\text { the end of the benchmark price [4] }\end{array}$ & $\begin{array}{l}\text { Relying on UHV power } \\
\text { grid, the formation of clean } \\
\text { energy-based, electricity as } \\
\text { the center of the energy } \\
\text { development and utilization } \\
\text { pattern, will fundamentally } \\
\text { alleviate China's air } \\
\text { pollution problems [5] }\end{array}$ & $\begin{array}{l}\text { China has achieved a } \\
\text { technology lead by its } \\
\text { comprehensive control } \\
\text { of UHV } \\
\text { AC transmission of the } \\
\text { core technology in the } \\
\text { world }\end{array}$ \\
\hline & Weakness & $\begin{array}{l}\text { Support for HVDC may } \\
\text { affect the allocation of } \\
\text { resources for AC } \\
\text { engineering }\end{array}$ & $\begin{array}{l}\text { With the construction of large- } \\
\text { scale comprehensive construction, } \\
\text { engineering cross, overdue period } \\
\text { of the phenomenon is more serious, } \\
\text { highlighting the construction of } \\
\text { resource problems }\end{array}$ & $\begin{array}{l}\text { Domestic projects may } \\
\text { cross natural reserves, a } \\
\text { good job of communication } \\
\text { and coordination need to be } \\
\text { took with the government }\end{array}$ & $\begin{array}{l}\text { The commercialization } \\
\text { of research findings has } \\
\text { a long cycle, Related } \\
\text { areas of production and } \\
\text { research integration is } \\
\text { not close enough. }\end{array}$ \\
\hline \multirow{2}{*}{ OT } & Opportunity & $\begin{array}{l}\text { The development of } \\
\text { global energy Internet has } \\
\text { created a grand blueprint } \\
\text { for UHV development. }\end{array}$ & $\begin{array}{l}\text { State Grid Corporation can support } \\
\text { the construction of UHV AC } \\
\text { engineering in the capital, human, } \\
\text { material and other aspects. }\end{array}$ & $\begin{array}{l}\text { As residents' awareness of } \\
\text { environmental protection is } \\
\text { increasing, UHV projects } \\
\text { can improve the } \\
\text { environment and gradually } \\
\text { gain social recognition. }\end{array}$ & $\begin{array}{l}\text { AC voltage of China } \\
\text { UHV is determined as } \\
\text { the international } \\
\text { standard voltage, the } \\
\text { Chinese standard has } \\
\text { been at the international } \\
\text { leader level.[6] }\end{array}$ \\
\hline & Threats & $\begin{array}{l}\text { A new round of power } \\
\text { system reform includes } \\
\text { the field of transmission } \\
\text { and distribution market } \\
\text { competition, the SGCC's } \\
\text { profit model may has a } \\
\text { fundamental change. }\end{array}$ & $\begin{array}{l}\text { China's economy touch the "new } \\
\text { normal", slowing the economic } \\
\text { growth. Supply side reform and } \\
\text { state-owned enterprise reform may } \\
\text { bring uncertainty to the } \\
\text { development of infrastructure. }\end{array}$ & $\begin{array}{l}\text { Overseas engineering in } \\
\text { have different political } \\
\text { stability, poor construction } \\
\text { and living environment, } \\
\text { which will challenges } \\
\text { construction stability. }\end{array}$ & $\begin{array}{c}\text { The developing } \\
\text { countries have poor } \\
\text { industrial base, raw } \\
\text { material production } \\
\text { capacity can't meet the } \\
\text { needs of large-scale } \\
\text { power grid construction. }\end{array}$ \\
\hline
\end{tabular}

\section{The Strategic ChOice OF THE DeVElopment OF UHV AC ENGINEERING}

At the end of 2004, the State Grid Corporation of China proposed the development of UHV transmission strategy under the economic and social development of China's growing demand for electricity and energy resources and consumption of the basic distribution of the basic situation.[7] There is no doubt that the UHV transmission strategy is a viable and necessary energy strategy option that fits our country's reality.

In line with the SWOT-PEST matrix analysis table above, for the listed difficulties and challenges, the State Grid Corporation of the top priority is to develop a good development strategy and response methods, the establishment of appropriate mechanisms to ensure the continued steady development of UHV communication projects. Specifically, the following aspects can be used for reference:

\section{A. The establishment of a number of projects coordination mechanism}

With the promotion of large-scale and high-voltage scale construction in China and abroad, the project intersects, the construction period is overlapped, and the problem of building resource is highlighted. Construction, test commissioning, other construction team resources and the main equipment supply materials is getting tighter. How to limit the construction of resources and equipment under a limited period of time to ensure that a number of projects to coordinate the promotion of large-scale construction and solve the context of resource bottlenecks is essential. The key to achieving effective co-ordination and avoiding the peak of key resources in a number of projects is the overall planning and scientific planning of the project. The peak of the project will be staggered, which will fundamentally solve the limited resources under the constraints of a number of projects to promote the coordination of resource bottlenecks. In addition, in the scientific schedule and overall planning, the peak of the demand for materials and equipment and the construction peak of each project should be staggered. But there are also major conflicts that may occur at other levels during the peak period and inconsistency issues need to be addressed timely, therefore the corresponding coordination mechanisms need to be established.

\section{B. Improve the technical level, strengthen the joint research with industry and research}

Strengthen equipment technology research and development. Increase the general tool, manufacturing and installation of test technology research and development efforts. The implementation of joint research and research with industry, deepening the discharge of GIS and other key issues of research, speed up the GIS transient over-voltage distribution, GIL manufacturing and installation and testing technology research and development and joint research, break the main transformer casing and lead connection structure, Spare phase full-load transport, seismic, noise and other technical difficulties. Promote the capacity transformer, railway transport transformers, composite surge arresters and other new equipment and phase selection to suppress the main 
transformer excitation inrush current joint research and application.

Increase the construction process technology joint research. Engineering construction technology is the main technology of engineering construction, through joint technical research; we can strengthen the construction process technology research and application, and sum up the experience of construction management from the practice. On one hand, strengthen the research and development, development suitable for UHV AC engineering characteristics of the construction technology, such as large-scale, long-distance cross-domain technology, high latitude, high-intensity operation management, submarine, river bottom cable laying and tunnel technology and many other content, What else continue to promote the whole process of mechanized construction and construction of new technology across the application; On the other hand, the technology should also be combined with the application of research and development, in particular, to strengthen the experience from the experience of production and research link feedback, so that can we enhance the practical application of research results by the whole process Closed-loop management and scientific and technological research and development of efficient conversion.

\section{Do a good job of overseas engineering various types of risk prediction and pre-control.}

In view of the stability of overseas construction problems, we must do a good job in risk prediction and control, specifically, in the market survey; we should pay attention to the local market survey, including the price of materials, site construction conditions and so on. In particular, we should pay attention to the understanding of legal policy, finance, foreign exchange, taxation, insurance, natural and social conditions, analyze the probability of occurrence of extreme impact, and formulate preventive measures. Human resources management, in accordance with the "less and fine" principle, choose the physical quality, ideological quality, excellent quality of service, a multi-skilled comprehensive talent. At the same time, we should choose qualified subcontractors team. To minimize the offshore project in the sub-team selection and management of various types of risks and to obtain construction management and decision-making first-hand information, we can send experienced first-line management personnel to the project country to conduct on-site field before we start the project. Material from different supplier must be approved by all departments, such as the owners, construction management units, design departments, construction units and so on. The list of materials to be collected by Party B must be compiled by experienced project chief engineer who has full knowledge of the construction process and approved by relevant functional departments. The name, specification, quantity, purpose, and time of arrival of the materials involved in the list of materials and materials shall be standardized, accurate and correct. What is more, overseas project subcontractors should encourage a number of subcontractors to participate in the subcontractor selection, so that we can control of subcontract costs through their competition. We should make pre-sub-package project planning as far as possible to achieve the balance of several sub-projects to avoid unnecessary disputes between subcontractors.

\section{CONCLUSION}

In the context of China's economy into the new normal era, the UHV AC transmission project will meet vast, long time period, technical challenges, the construction of UHV AC transmission project is a also a difficult task, which requires the majority of builders to use advanced management methods and technical means, we must participate in UHV Engineering construction, for our efficient, environmentally friendly energy allocation[8]

\section{REFERENCES}

[1] Yao lei,Zeng hui-juan. UHV: China Science and Technology of the new business card [N]. State Grid News,2014-05-19001. (In Chinese)

[2] Yang lei-peng. Study on the Cultivation and Promotion of Market Competitiveness of Dongtai Phase I Cogeneration Project [D]. North China Electric Power University (Beijing),2008. (In Chinese)

[3] Liu chun-ying,Xiaona. Discussion on the Development Model of Bioenergy Industry in China Based on SWOT - PEST Model [J]. Business age,2011,18:112-113. (In Chinese)

[4] Bai jian-hua. UHV transmission energy economic environment is huge [J]. State Grid,2014,06:28-31.

[5] Liu zhen-ya. Develop the UHV power grid, crack haze dilemma [J]. State Grid,2014,03:16-17. (In Chinese)

[6] Zhai jian. China 's UHV standard "lead" the world [N]. Science and Technology Daily,2014-03-27003. (In Chinese)

[7] Luan hao,Shi shu-de. Cooperative Innovation Practice of UHV AC Engineering in National Power Grid [J]. Petroleum Science and Technology Forum,2015,05:60-63. (In Chinese)

[8] Zhao zheng. Discussion on Development Strategy of UHV Power Grid in China [J]. Science and Technology Innovation, 2015,17:35. (In Chinese) 